\title{
INTERACTION BETWEEN DIETARY MINERAL AND PHYTASE ON BIOLOGICAL PERFORMANCES OF JAPANESE FLOUNDER, Paralichthys olivaceus. PART II. MINERAL DIGESTIBILITY AND VERTEBRAL MINERAL CONTENT
}

\author{
Asda Laining"\#, Lideman"), and Shunsuke Koshio" \\ ") Research and Development Institute for Coastal Aquaculture \\ ") Brackishwater Aquaculture Development Centre, Takalar, South Sulawesi \\ "m) Lab. of Aquatic Animal Nutrition, Fac. of Fisheries, Kagoshima University, Japan
}

(Received 26 September 2014; Final revised 14 April 2015; Accepted 8 June 2015)

\begin{abstract}
Interactive effects between dietary inorganic phosphorus (IP) and phytase (P) on mineral digestibility and vertebral mineral content were investigated in a 30 days feeding trial followed by three weeks digestibility trial with Japanese flounder, Paralichthys olivaceus. Eight experimental diets were formulated based on two levels of dietary Ca at $0 \%$ and $0.2 \%$ combined with either $0 \%$ or $0.25 \%$ of dietary IP and either with 0 and 2,000 fytase unit (FTU)/kg of phytase in diet, respectively. Result indicated that digestibility of total phosphorus significantly increased by three dietary compounds where the highest was observed in fish fed diet contained $0.25 \%$ IP and 2,000 FTU phytase/kg and dietary Ca also included in diet. Significant interaction was only detected between dietary IP and P on this parameter. Supplementation of IP and Ca not phytase significantly improved Ca digestibility. Ca digestibility was very poor when dietary IP and Ca were not supplemented in diet even with when phytase supplemented in diet. There was significant interaction between dietary IP and $\mathrm{Ca}$ on $\mathrm{Ca}$ digestibility. Vertebral total phosphorus, $\mathrm{Ca}$, and $\mathrm{Mg}$ content as well as $\mathrm{Ca}: \mathrm{P}$ ratio were significantly enhanced by dietary IP and phytase. Dietary Ca has significant effect only on vertebral total phosphorus. Interaction between dietary IP and Ca was significantly found on vertebral Ca content and Ca:P ratio. No significant second-order interaction was observed among the three dietary mineral on overall parameters. Based on total phosphorus and Ca digestibility as well vertebral phosphorus content found in this study, dietary IP, Ca, and phytase at rate of $0.25 \%, 0.2 \%$, and 2,000 FTU phytase $/ \mathrm{kg}$ diet, respectively are needed to supplement in diet for a better mineral absorption and bone mineralization.
\end{abstract}

KEYWORDS: mineral, phytase, digestibility, vertebrae, Japanese flounder

\section{INTRODUCTION}

Calcium (Ca) is likely not crucial for aquatic species since natural waters contain appreciable amount of Ca that can be utilized to meet a part or full of the metabolic Ca requirement of fishes. Fish can take soluble Ca from the water by drinking and by direct absorption through gills, epidermis or both (Deshimaru et al., 1978). However, it is still contradictory whether fish can met the Ca requirement in large part by absorb this ions directly from aquatic environment or need to fulfill their requirement from aqua-feed. In case of brown trout (Templeton $\&$ Brown, 1963), goldfish (Ichii \& Mugiya, 1983), black sea bream

\# Corresponding: Research and Development Institute for Coastal Aquaculture. Jl. Makmur Dg. Sitakka No. 129, Maros 90512, South Sulawesi, Indonesia. Tel.: + (0411) $371544 / 5$; E-mail: asdalaining@yahoo.com
(Hossain \& Furuichi, 1999a), and also abalone (Coote et al., 1996), dietary Ca may not be necessary as they can easily absorb from the surrounding water. In contrast, several species such as giant croaker, red mullet (Hossain \& Furuichi, 1999b; 2000) need dietary $C a$, even white shrimp, Penaeus vannamei and $P$. japonicus required higher level of dietary Ca than fish species (Davis \& Arnold, 1994; Davis \& Lowrence, 1997).

Regarding phosphorus requirement in fish, many studies have proved the importance of supplementing dietary phosphorus in aqua-feed including marine species (Lall, 2002; Uyan et al., 2007; Laining et al., 2012). Moreover, enhancement of phosphorus utilization originated from phytic acid through supplementing phytase in diet have also been widely reported ((Applegate et al., 2003; Tamim et al., 2004; Kemme et al., 2006; Liebert \& Portz, 2007). Even 
though, many studies on mineral requirement have been reported on aquatic species, still few studies reported the interrelation between mineral in fish. Relationship between mineral can be synergetic and antagonistic interrelationships (Lall, 2002; Apines et al., 2003; Laining et al., 2011).

The present study is based on material from an interactive study between $\mathrm{Ca}$ and phosphorus $(\mathrm{P})$ with presence of dietary phytase on growth, feed intake, and whole body mineral (Laining et al., 2013). The results presented here in emphasize the interactive effect of the dietary $\mathrm{Ca}$ and $\mathrm{P}$ combined either with or without phytase on mineral digestibility and mineral content in vertebrae of juvenile Japanese flounder.

\section{MATERIALS AND METHODS}

\section{Test Diet}

Eight experimental diets were formulated to contain two levels of dietary $\mathrm{Ca}$ at $0 \%$ and $0.2 \%$ and $\mathrm{P}$ at $0 \%$ and $0.25 \%$ and phytase supplementation at 0 and $2,000 \mathrm{FTU} / \mathrm{kg}$ diet. This experiment was arranged according to Factorial Design $2 \times 2 \times 2$ with triplicates. Formulation of the test diets were presented in Table 1. Diet 1 and 2 were supplemented without both $\mathrm{Ca}$ and $\mathrm{P}$ combined either without or with phytase supplementation, respectively; diet 3 and 4 were supplemented with $0.25 \% \mathrm{P}$ without $\mathrm{Ca}$ combined either without or with phytase supplementation, respectively; diet 5 and 6 were added with $0.2 \%$

Table 1. Formulation of experimental diets containing different level of dietary Ca, IP, and phytase supplementation

\begin{tabular}{|c|c|c|c|c|c|c|c|c|}
\hline \multirow{2}{*}{$\begin{array}{l}\text { Ingredients } \\
\qquad(\%)\end{array}$} & \multicolumn{8}{|c|}{$\begin{array}{c}\text { Experimental diets } \\
\text { (IP = Inorganic phosphorus; } \mathrm{Ca}=\text { Calcium; } \mathrm{NP}=\text { Non-phytase } \mathrm{P}=\text { Phytase })\end{array}$} \\
\hline & $\begin{array}{c}0 \mathrm{IP} / \\
0 \mathrm{Ca} / \mathrm{NP}\end{array}$ & $\begin{array}{c}0 \mathrm{IP} / \\
0 \mathrm{Ca} / \mathrm{P}\end{array}$ & $\begin{array}{l}0.25 \mathrm{IP} / \\
0 \mathrm{Ca} / \mathrm{NP}\end{array}$ & $\begin{array}{l}0.25 \mathrm{IP} / \\
0 \mathrm{Ca} / \mathrm{P}\end{array}$ & $\begin{array}{c}0 \mathrm{IP} / \\
0.2 \mathrm{Ca} / \mathrm{NP}\end{array}$ & $\begin{array}{c}0 \mathrm{IP} / \\
0.2 \mathrm{Ca} / \mathrm{P}\end{array}$ & $\begin{array}{c}0.25 \mathrm{IP} / \\
0.2 \mathrm{Ca} / \mathrm{NP}\end{array}$ & $\begin{array}{l}0.25 \mathrm{IP} / \\
0.2 \mathrm{Ca} / \mathrm{P}\end{array}$ \\
\hline Brown fishmeal & 18 & 18 & 18 & 18 & 18 & 18 & 18 & 18 \\
\hline Krill meal & 8 & 8 & 8 & 8 & 8 & 8 & 8 & 8 \\
\hline Soybean protein isolate ${ }^{1}$ & 30 & 30 & 30 & 30 & 30 & 30 & 30 & 30 \\
\hline Dextrin-hydrate & 10 & 10 & 10 & 10 & 10 & 10 & 10 & 10 \\
\hline$\alpha$-Starch & 5 & 5 & 5 & 5 & 5 & 5 & 5 & 5 \\
\hline Pollack liver oil & 5 & 5 & 5 & 5 & 5 & 5 & 5 & 5 \\
\hline HUFA $^{2}$ & 1 & 1 & 1 & 1 & 1 & 1 & 1 & 1 \\
\hline Activated gluten & 6 & 6 & 6 & 6 & 6 & 6 & 6 & 6 \\
\hline Vitamin $\operatorname{mix}^{3}$ & 3 & 3 & 3 & 3 & 3 & 3 & 3 & 3 \\
\hline Stay- $C^{4}$ & 0.1 & 0.1 & 0.1 & 0.1 & 0.1 & 0.1 & 0.1 & 0.1 \\
\hline Ca-P-free mineral mix ${ }^{5}$ & 4 & 4 & 4 & 4 & 4 & 4 & 4 & 4 \\
\hline Sodium monophosphate ${ }^{6}$ & 0 & 0 & 1.1 & 1.1 & 0 & 0 & 0 & 0 \\
\hline Calcium carbonate $^{7}$ & 0 & 0 & 0 & 0 & 0.5 & 0.5 & 0.5 & 0.5 \\
\hline Phytase $^{8}$ & 0 & 0.04 & 0 & 0.04 & 0 & 0.04 & 0 & 0.04 \\
\hline Attractant $^{9}$ & 0.2 & 0.2 & 0.2 & 0.2 & 0.2 & 0.2 & 0.2 & 0.2 \\
\hline$\alpha$-Cellulose & 9.7 & 9.66 & 8.6 & 8.56 & 9.2 & 9.16 & 8.1 & 8.06 \\
\hline Total & 100 & 100 & 100 & 100 & 100 & 100 & 100 & 100 \\
\hline \multicolumn{9}{|c|}{1 Soybean protein isolate obtained from Fuji Pro Company, Tokyo, Japan } \\
\hline \multicolumn{9}{|c|}{2 Poweash A, Oriental Yeast Co, Ltd, Tokyo, Japan. } \\
\hline \multicolumn{9}{|c|}{$\begin{array}{l}3 \text { Vitamin mixture }(\mathrm{g} / \mathrm{kg} \text { diet): } \beta \text {-carotene } 0.192 \text {; vitamin } \mathrm{D} 30.019 \text {; menadione } 0.0917 \text {; } \alpha \text {-tocopherol acetate } 0.77 \text {; thiamin nitrate } \\
0.115 \text {; riboflavin } 0.385 \text {; pyridoxine-HCl } 0.092 \text {; cyanocobalamin } 0.00018 \text {; d-biotin } 0.0115 \text {; inositol } 7.698 \text {; nicotinic acid } 1.539 \text {; Ca- } \\
\text { pantothenate } 0.5391 \text {; folic acid } 0.0288 \text {; choline chloride } 15.738 \text {; } \rho \text {-aminobenzoic acid } 0.7665 \text {; cellulose } 2.849\end{array}$} \\
\hline \multicolumn{9}{|c|}{${ }^{4}$ Ascorbic acid monophosphate-Mg. } \\
\hline \multirow{2}{*}{\multicolumn{9}{|c|}{ 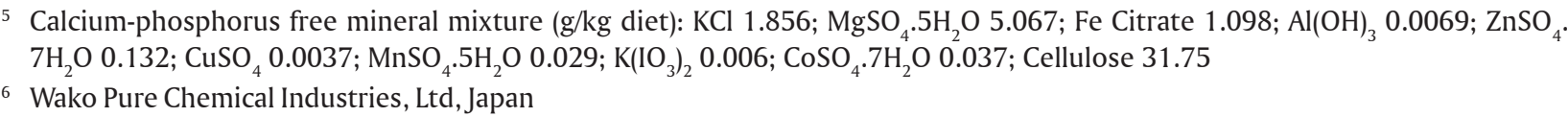 }} \\
\hline & & & & & & & & \\
\hline \multicolumn{9}{|c|}{7 Wako Pure Chemical Industries, Ltd, Japan } \\
\hline \multicolumn{9}{|c|}{8 Ronozyme P5000, DSM Nutritional Product Ltd, Basel, Switzerland $(0.04 \%=2,000$ FTU/kg diet) } \\
\hline Attractant ( $\mathrm{g} / \mathrm{kg}$ diet): beta & & & & & & & & \\
\hline
\end{tabular}


Ca without $\mathrm{P}$ combined either without and with phytase supplementation; diet 7 and 8 were included with $0.2 \% \mathrm{Ca}$ and $0.25 \% \mathrm{P}$ combined either without and with phytase supplementation, as previously. Commercial phytase (Ronozyme P5000, DSM Nutritional Product Ltd, Basel, Switzerland) was used as phytase source produced from Peniophora lycii by submerged fermentation of a genetically modified Aspergillus oryzae strain with activity of 5,000 FTU/g. Sodium mono-phosphate $\left(\mathrm{NaH}_{2} \mathrm{PO}_{4}\right)$ and calcium carbonate $\left(\mathrm{CaCO}_{3}\right)$ were used as IP and Ca sources.

All dry ingredients were weighed and mixed, then added the lipid source and mixed again until homogenized. Deionized water was added $\left(300 \mathrm{~mL} \mathrm{~kg}^{-1}\right.$ dry ingredients mixture) and mixed again. The wet dough was pelletized using meat chopper, and then dried with oven at $40^{\circ} \mathrm{C}$ until moisture content between $10 \%-15 \%$. Dried pellet was kept at $-20^{\circ} \mathrm{C}$ until use and during the feeding trial, all diets were stored at $5^{\circ} \mathrm{C}$.

\section{Fish and Culture Condition}

Five hundred juvenile Japanese flounder were obtained from a domestic hatchery (Matsumoto Suisan Co., Miyazaki, Japan) and acclimatized for one week using commercial diet (Higashimaru, Kagoshima, Japan). Fish with average initial body weight (IBW) 0.61 $\pm 0.0 \mathrm{~g}$ (mean $\pm \mathrm{SD}$ ) were randomly distributed into 24 tanks of $100 \mathrm{~L}$ capacity at a density of $20 \mathrm{fish} / \mathrm{tank}$. Each tank was supplied with filtered seawater with flow through system at a flow rate of $1.2 \mathrm{~L} /$ minutes. Fish were fed the experimental diets twice a day to nearly satiation (8.00 and 16.00 ) for 30 days. Water temperature during feeding trial ranged from $19^{\circ} \mathrm{C}$ to $21^{\circ} \mathrm{C}$.

\section{Vertebral Sampling}

At the end of the feeding trial, five fish from each tank representing the mean body weight were taken for vertebrae samples. Fish were dissected and vertebrae were removed by heating for three min. with microwave, then clean of connective tissues and finally washed with deionized water. The vertebrae were defatted by chloroform-methanol (2:1) extraction according to Folch et al. (1957). Defatted vertebrae were dried and pulverized with mortar and pestle, and stored at $-20^{\circ} \mathrm{C}$ until analysis.

\section{Chemical Analysis}

Proximate analysis including moisture, crude protein, lipid, and ash for experimental diet and whole body were carried out based on AOAC (1995) procedures. Measurement of $\mathrm{pH}$ in stomach and intestine of fish was determined by making slurry of the gut content with distilled water and using a pH electrode. Analysis of total P for diet, whole body, feces, and vertebrae were carried out according to Lowry \& Lopez (1946). Phytic acid content of test diet was determined spectro-photometrocally based on Haugh \& Lantzch (1959). In-feed analysis of phytase activity was carried out according to the procedure of Engelen et al. (1994). Mineral content of diets feces and vertebrae were analyzed using AAS after acid digestion.

\section{Digestibility Trial}

A digestibility trial was conducted after a 30 days feeding trial using remained fish in stocked tank from similar batch used for feeding trial. Fish were randomly distributed into duplicate tanks with density

Table 2. Chemical composition of experimental diets containing different level of dietary Ca, IP, and phytase supplementation

Experimental diets

\begin{tabular}{|c|c|c|c|c|c|c|c|c|}
\hline \multirow{2}{*}{$\begin{array}{l}\text { Nutrients } \\
\text { (\%) }\end{array}$} & \multicolumn{8}{|c|}{$\begin{array}{l}\text { Experimental diets } \\
(\text { IP = Inorganic phosphorus; } \mathrm{Ca}=\text { Calcium; } \mathrm{NP}=\text { Non-phytase } \mathrm{P}=\text { Phytase })\end{array}$} \\
\hline & $\begin{array}{c}0 \mathrm{IP} / \\
0 \mathrm{Ca} / \mathrm{NP}\end{array}$ & $\begin{array}{c}0 \mathrm{OIP} / \\
0 \mathrm{CCa} / \mathrm{P}\end{array}$ & $\begin{array}{l}0.25 \mathrm{IP} / \\
0 \mathrm{Ca} / \mathrm{NP}\end{array}$ & $\begin{array}{c}0.25 \mathrm{IP} / \\
0 \mathrm{Ca} / \mathrm{P}\end{array}$ & $\begin{array}{c}0 \mathrm{IP} / \\
0.2 \mathrm{Ca} / \mathrm{NP}\end{array}$ & $\begin{array}{c}0 \mathrm{IP} / \\
0.2 \mathrm{Ca} / \mathrm{P}\end{array}$ & $\begin{array}{c}0.25 \mathrm{IP} / \\
0.2 \mathrm{Ca} / \mathrm{NP}\end{array}$ & $\begin{array}{l}0.25 \mathrm{IP} / \\
0.2 \mathrm{Ca} / \mathrm{P}\end{array}$ \\
\hline Crude protein & 49.2 & 48.9 & 50.9 & 47.6 & 47.9 & 47.7 & 47.4 & 47.5 \\
\hline Total lipid & 11.5 & 11.7 & 11.5 & 11.2 & 11.4 & 11.1 & 11.0 & 11.3 \\
\hline Ash & 6.9 & 6.9 & 7.6 & 7.3 & 7.4 & 7.2 & 8.1 & 7.9 \\
\hline Phytic acid/IP6 & 0.55 & 0.52 & 0.53 & & 0.53 & 0.58 & 0.58 & 0.59 \\
\hline Phytase (FTU/kg) & 248.4 & $1,961.70$ & 197.5 & $2,093.10$ & 214.7 & $1,918.50$ & 362.1 & $2,031.90$ \\
\hline \multicolumn{9}{|l|}{ Minerals content: } \\
\hline Total P & 0.86 & 0.84 & 1.08 & 1.13 & 0.88 & 0.89 & 1.13 & 1.15 \\
\hline $\mathrm{Ca}$ & 1.19 & 1.19 & 1.21 & 1.20 & 1.37 & 1.39 & 1.37 & 1.39 \\
\hline $\mathrm{Mg}$ & 0.15 & 0.18 & 0.18 & 0.17 & 0.17 & 0.16 & 0.16 & 0.17 \\
\hline $\mathrm{Zn}(\mathrm{mg} / \mathrm{g})$ & 0.08 & 0.09 & 0.09 & 0.08 & 0.08 & 0.08 & 0.08 & 0.07 \\
\hline Ca : P ratio & 1.38 & 1.42 & 1.12 & 1.06 & 1.56 & 1.56 & 1.21 & 1.20 \\
\hline
\end{tabular}


of 10 fish/tank. The average body weight (ABW) of fish were $8.5 \pm 0.2 \mathrm{~g}$. Chromium oxide $\left(\mathrm{Cr}_{2} \mathrm{O}_{3}\right)$ was added to test diets as inert indicator at level of $0.5 \%$. Test fish were fed the diets containing $\mathrm{Cr}_{2} \mathrm{O}_{3}$ under the same condition of the feeding trial. After 5 days adaptation of those diets, feces collection started at three hours interval between the morning and afternoon feeds by using a siphon. Feces collection continued for 10 days until sufficient amounts of feces for analysis were collected. Feces were freeze-dried and kept at $-20^{\circ} \mathrm{C}$ until the analysis. Concentration of $\mathrm{Cr}_{2} \mathrm{O}_{3}$ in test diet and feces were determined according to Furukawa \& Tsukahara (1966). Apparent digestibility coefficient of nutrients (ADC, \%) were calculated according to Bureau et al. (2002) as follow:

$$
\mathrm{ADC}(\%)=\frac{\% \mathrm{Cr} \text { in diet }}{\% \mathrm{Cr} \text { in feces }} \times \frac{\% \mathrm{~N} \text { in feces }}{\% \mathrm{~N} \text { in diet }} \times 100 \%
$$

where:

$\mathrm{Cr}$ is chromium oxide $\left(\mathrm{Cr}_{2} \mathrm{O}_{3}\right)$ and $\mathrm{N}$ is nutrient

\section{Statistical Analysis}

Data were subjected to three-way ANOVA $(\mathrm{P}<$ $0.05)$ to identify significant differences among treatments.

\section{RESULTS AND DISCUSSIONS}

\section{Digestibility of $\mathrm{P}$ and $\mathrm{Ca}$}

The dietary Ca, IP, and phytase significantly enhanced the digestibility of $\mathrm{P}$. The lowest $\mathrm{P}$ digestibility was observed in fish fed the diet without all dietary treatments $(29 \%)$ and slightly improved by supplementation $\mathrm{Ca}$ at $0.2 \%$ (31.6\%). Inclusion of either dietary IP or phytase at $0 \% \mathrm{Ca}$ had a similar effect on $\mathrm{P}$ digestibility and were significant higher compared when fish fed only dietary Ca (35.8\% vs $36.0 \%$ vs $31.6 \%$, respectively) (Table 3). When both dietary IP and phytase were supplemented in diet, P digestibility was much higher (48\%) even without adding dietary Ca. Moreover, presence of the three dietary treatments yielded to the highest $\mathrm{P}$ digestibility (54.4\%) among groups. Based on the 3-ways ANOVA, only interactive effect between dietary IP and phytase was detected on P digestibility (Table 3).

Digestibility of Ca was significantly enhanced by dietary $\mathrm{Ca}$ and IP, but not phytase. Fish fed two diets without $\mathrm{Ca}$ and IP supplements had the lowest $\mathrm{Ca}$ digestibility and significantly increased by supplementing either with dietary IP or Ca. Supplementation of both dietary IP and $\mathrm{Ca}$ in diet had significant higher Ca digestibility compared the un-supplemented groups. In addition, interactive effect between dietary $\mathrm{Ca}$ and IP was significantly detected on Ca digestibility.

\section{Vertebral Mineral Contents}

Concentration of $\mathrm{P}, \mathrm{Ca}, \mathrm{Mg}$ in vertebral as well as $\mathrm{Ca}: \mathrm{P}$ ratio was shown in Table 4. Vertebral P content significantly improved by dietary $\mathrm{Ca}$, IP, and phytase supplements. Fish fed diet without the three dietary treatments had the lowest vertebral P content. Similar to P digestibility, when the diet was only supplemented with $0.2 \% \mathrm{Ca}$, vertebral $\mathrm{P}$ content was significant lower than when the diet contained either dietary IP or phytase. Presence of dietary Ca, IP, and phytase in diet had the highest vertebral $\mathrm{P}$ content (11.5\%) but only slight different from vertebral $P$ content of fish fed diet contained IP and phytase without Ca (11.3\%). Both dietary IP and phytase, not dietary Ca significantly improved Ca content in vertebral. The lowest vertebral Ca content was found in fish fed diet without all dietary treatments, and did not significantly increase by supplementing $\mathrm{Ca}$ at

Table 3. Digestibility of $\mathrm{P}$ and Ca of juvenile Japanese flounder fed diet containing different level of Ca, $\mathrm{P}$, and dietary phytase supplementation

\begin{tabular}{|c|c|c|c|c|c|c|c|c|}
\hline \multirow{2}{*}{ Parameters } & \multicolumn{8}{|c|}{$\begin{array}{l}\text { Experimental diets } \\
(\text { (IP = Inorganic phosphorus; } \mathrm{Ca}=\text { Calcium; } \mathrm{NP}=\text { Non-phytase } \mathrm{P}=\text { Phytase })\end{array}$} \\
\hline & $\begin{array}{c}10 \mathrm{IP} / \\
0 \mathrm{Ca} / \mathrm{NP}\end{array}$ & $\begin{array}{c}0 \mathrm{IP} / \\
0 \mathrm{Ca} / \mathrm{P}\end{array}$ & $\begin{array}{l}0.25 \mathrm{IP} / \\
0 \mathrm{Ca} / \mathrm{NP}\end{array}$ & $\begin{array}{l}0.25 \mathrm{IP} / \\
0 \mathrm{Ca} / \mathrm{P}\end{array}$ & $\begin{array}{c}0 \mathrm{IP} / \\
0.2 \mathrm{Ca} / \mathrm{NP}\end{array}$ & $\begin{array}{c}0 \mathrm{IP} / \\
0.2 \mathrm{Ca} / \mathrm{P}\end{array}$ & $\begin{array}{c}0.25 \mathrm{IP} / \\
0.2 \mathrm{Ca} / \mathrm{NP}\end{array}$ & $\begin{array}{l}0.25 \mathrm{IP} / \\
0.2 \mathrm{Ca} / \mathrm{P}\end{array}$ \\
\hline P digestibility (\%) & 29.11 & 35.97 & 35.77 & 48.08 & 31.61 & 38.27 & 43.16 & 54.4 \\
\hline Ca digestibility (\%) & 5.41 & 6.99 & 28.82 & 28.23 & 20.13 & 23.49 & 29.15 & 26.96 \\
\hline $\begin{array}{l}\text { Three-way ANOVA } \\
\text { Pvalue }\end{array}$ & IP & $\mathrm{Ca}$ & Phytase & Ca $\times$ IP & IP x Phytase & Ca x Phytase & IP x Ca x & Phytase \\
\hline P digestibility & $\mathrm{S}$ & $\mathrm{S}$ & $\mathrm{S}$ & NS & $\mathrm{S}$ & NS & $\Lambda$ & \\
\hline Ca digestibility & $S$ & $\mathrm{~S}$ & NS & $S$ & NS & NS & $\Lambda$ & \\
\hline
\end{tabular}

Note: $\mathrm{S}=$ Significant; $\mathrm{NS}=$ Non significant 
Table 4. Mineral content in vertebral of juvenile Japanese flounder (\%)

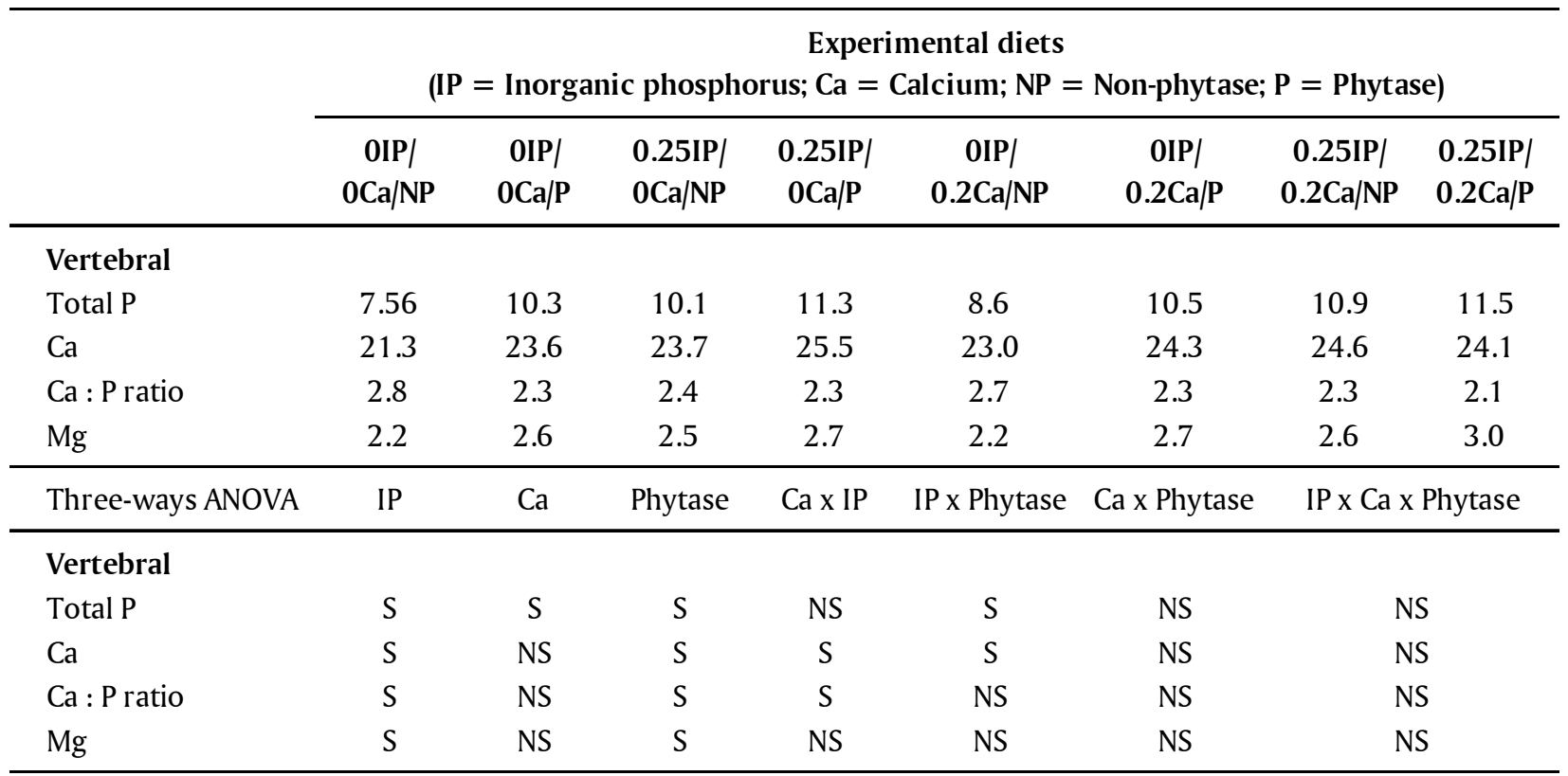

Note: $\mathrm{S}=$ Significant; NS = Non significant

$0.2 \%$. However, it was significantly improved by inclusion of either dietary IP or phytase. When diet contained dietary IP and phytase, vertebral Ca was in the highest content even without supplemental Ca. Furthermore, statistical analysis detected significant interaction between dietary Ca and IP and between dietary $\mathrm{Ca}$ and phytase as well. However, second-order interaction was not observed on this parameter (Figure 1).

Similar to vertebral Ca content, dietary Ca did not significantly affect vertebral $\mathrm{Mg}$ content. Fish fed diet without Ca, IP, and phytase supplement had the same vertebral $\mathrm{Mg}$ content around $2.2 \%$ as fish fed diet contained only dietary Ca. Inclusion of dietary phytase without dietary IP significantly elevated vertebral Mg content and its effect was similar at two level of dietary Ca $(2.64 \%$ and $2.67 \%$, respectively). Moreover, when both dietary IP and phytase were supplemented, vertebral $\mathrm{Mg}$ content became much higher particularly at $0.2 \%$ Ca supplement around 3.0\%. However, interactions among three dietary treatments were not detected.

Our previous study indicated that presence of either dietary supplemental IP or phytase significantly enhanced the growth of red sea bream (Laining et al., 2012). In addition, growth of Japanese flounder significantly enhanced by supplementing either dietary IP or phyatse even when Ca did not present in the diet and highest SGR was found when these three nutrients were included together (Laining et al., 2013). This finding indicated that Japanese flounder seemed to have the capacity to uptake Ca from seawater to meet the requirement level for growth which supported the previous results found in tiger puffer (Laining et al., 2011). Flik et al. (1995) reported that Ca is actively absorbed through the gill epithelium in freshwater fish whereas in marine fish $\mathrm{Ca}$ is transported across the intestinal epithelium. Since Ca digestibility of two diets containing no dietary Ca and IP was very low, it seemed that fish in this group mainly utilize Ca uptake from the water for growth. On the other hand, flounder had a low ability to digest Ca from organic sources as indicated by higher Ca digestibility in fish fed $0.2 \%$ Ca than un-supplemented group (20.1\% vs $5.4 \%)$. In contrast, Hossain \& Furuichi (2000) reported that absorption of Ca from seawater was not adequate for the growth of juvenile Japanese flounder. The discrepancy between these studies, perhaps due to the difference in feed ingredients used in basal diets. In the previous study, casein based diet was used as the basal diet containing around $0.02 \% \mathrm{Ca}$, while in the present study, fishmeal, krill meal, and soy protein isolate (SPI) were used as the protein sources which contained around 5.6\%, $1.6 \%$, and $0.1 \% \mathrm{Ca}$, respectively contributing around $1.2 \% \mathrm{Ca}$ in basal diet. In the present study, even though Ca digestibility of basal diet was only $5.4 \%$, it contributed around $0.06 \%$ Ca which was higher compared to $0.02 \% \mathrm{Ca}$ in basal diet used in the previous study. It is likely that Ca from the organic sources was at least partially available and utilized by flounder along with Ca from waterborne. This was in accordance with the result found by Hossain \& Furuichi (2000) that flounder fed $0.2 \%$ Ca from tricalcium phosphate (TCP), the main form of Ca-P in fishmeal, had 
Response at $0 \%$ Ca

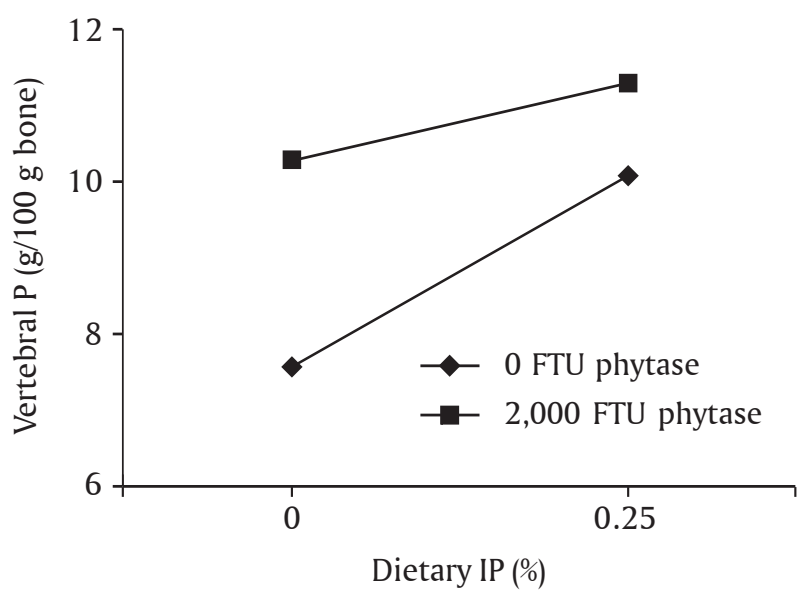

Response at $0.2 \% \mathrm{Ca}$

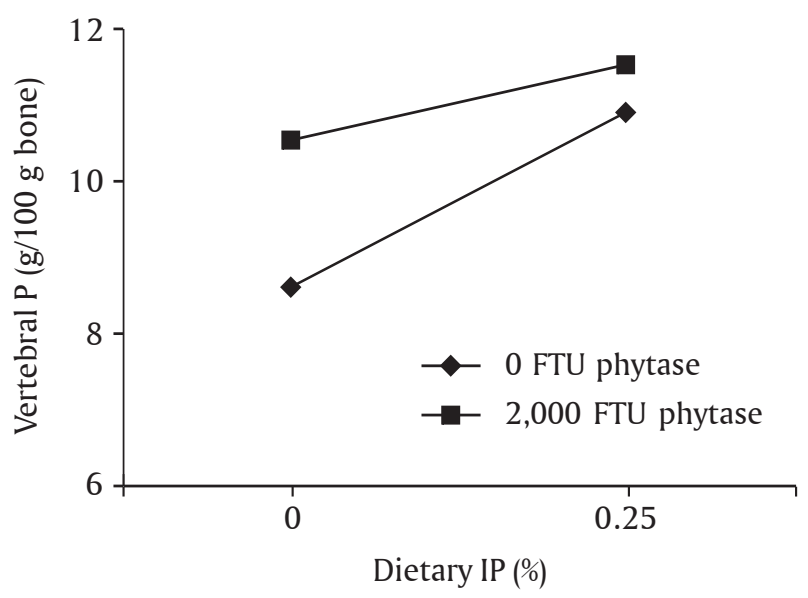

Figure 1. Mean plot of non second-order interaction (interaction between dietary IP x Ca $\mathrm{x}$ phytase) on vertebral $\mathrm{P}$ content at two levels of dietary Ca. Each graph illustrated the interaction effect between dietary IP and phytase on vertebral P (data from Table 4)

significant higher growth compared to un-supplemented group. However, inclusion of high level of $2.5 \%$ TCP had negative effect on growth of flounder.

Japanese flounder seemed unable to digest not only P from fishmeal but also P from SPI indicated with the lowest $\mathrm{P}$ digestibility in fish fed diet without Ca, IP, and phytase supplement, but become higher when dietary phytase or IP was supplemented in diet. This response indicated that flounder lacked the endogenous phytase to hydrolyze the phosphate groups from inositiol ring of IP6 which supported the previous results found in red sea bream (Laining et al., 2012) and earlier finding on other species (Vielma et al., 2002; Liebert \& Portz, 2007; Sardar et al., 2007). Moreover, it is interesting that dietary Ca had a slight but significant effect in increasing P digestibility (from $29.1 \%$ to $31.6 \%$ ). In return, dietary IP significantly enhanced Ca digestibility from $5.4 \%$ to $28 \%$. This may suggest that to a certain extent there was a synergistic relationship between dietary Ca and IP in absorption of both minerals in intestines as indicated by the significant interaction between dietary $\mathrm{Ca}$ and IP supplement on Ca digestibility. One of important functions of $\mathrm{Ca}$ is to maintain the cell membrane integrity. In membrane cell, Ca is closely bound to phospholipid where it controls the permeability of membrane thus regulate the uptake nutrients by the cell (Lall, 2002). Several nutrient interrelationships are well known in terrestrial animal and human nutrition (McDowell, 1992). In aquatic animal, potential of mineral-mineral interactions had also been reported (Hilton, 1989) that the interrelationship may manifest themselves as a requirement for one element for the proper metabolism of another or as competition for binding sites on transport or storage molecules.
Dietary Ca, IP, and phytase supplement significantly elevated vertebral P content. Unlike Ca supplementation into the diet containing $0.25 \%$ IP or $2,000 \mathrm{FTU}$ phytase $/ \mathrm{kg}$, effect of supplemental Ca on vertebral P content was more pronounced when both dietary IP and phytase did not include in the diet. Similar response was reported on Atlantic salmon that $\mathrm{Ca}$ supplementation of the basal diet enhanced $\mathrm{Ca}$ and $\mathrm{P}$ mineralization, but no effect when diet contained $0.6 \%$ IP (Vielma \& Lall, 1998). It is well accepted that freshwater fish actively transport ionic from the water through gills, whereas in seawater, branchial Ca uptake is inhibited (Flik et al., 1995) meaning that enhancement of vertebral $\mathrm{P}$ deposition by dietary $\mathrm{Ca}$ supplement may have resulted from a specific dietary Ca requirement by Japanese flounder. Even though, dietary Ca (unlike dietary IP and phytase) had no significant effect on vertebral $\mathrm{Ca}$, significant interaction between dietary $\mathrm{Ca}$ and IP on vertebral $\mathrm{Ca}$ content indicated that effect of dietary IP on P accumulation in vertebrae is influenced by dietary Ca.

Supplementation of dietary Ca at level of $0.2 \%$ did not induce the inhibitory effect on $\mathrm{P}$ and $\mathrm{Mg}$ accumulation in vertebrae indicating that this level was not over-dosage that may interfere with other mineral availability. Intestinal interactions between $\mathrm{Mg}$ and $\mathrm{Ca}$ or $\mathrm{P}$ are well documented in terrestrial vertebrates as well as fish as found in tiger puffer (Laining et al., 2011). Dietary requirement of $\mathrm{Mg}$ have been reported on several species such as tilapia (Flik et al., 1993), carp (van der Velden et al., 1992) and rainbow trout (Shearer \& Asgard, 1992). No significant effect of dietary $\mathrm{Ca}$ on vertebral $\mathrm{Ca}$ content revealed that bone is not the major site of Ca regulation in fish which is different from terrestrial animals. According to Lall \& Lewis-McCrea (2007), Ca regulation occurs at the gills, 
fins, and oral epithelia tissues. In addition, Mugiya \& Watanabe (1977) observed that following an estrogen injection in goldfish and killifish, Ca mobilized into the plasma from scale but not from bone.

Studies on $\mathrm{P}$ requirement in salmonids showed that in many cases, bone or total body ash has been at least as sensitive as growth for evaluating P utilization (Watanabe et al., 1980; Rodehutscord, 1996; Asgard \& Shearer, 1997). In this present study, whole body ash was not analyzed due to the insufficient samples. However, enhancement of vertebral $\mathrm{P}$ and $\mathrm{Mg}$ content by both dietary IP and phytase found in this present study supported the previous results that bone mineralization can be used as indicators of dietary P utilization. Inclusion of 2,000 FTU phytase/ $\mathrm{kg}$ diet resulted in a significant elevated vertebral $\mathrm{Mg}$ content indicating that after being degraded by phytase, chelating effect of IP6 become decreased.

In this present study, interactive effect among three dietary treatments of Ca, IP, and phytase or also called second-order interaction was not significantly detected on all parameters including on growth performances and feed utilization as reported previously (Laining et al., 2013). Second order interaction can be interpreted as indicating that interaction between $\mathrm{Ca}$ and IP differs depending on the level of phytase or interaction between $\mathrm{Ca}$ and phytase depending on the level of IP, and so on (Toutenburg, 2002). Therefore interaction between dietary Ca and IP on Ca digestibility (for example) was not influenced by dietary phytase level since no second order interaction was found in this parameter.

\section{CONCLUSION}

In conclusion, dietary $\mathrm{Ca}$, IP, and phytase supplement significantly enhanced the digestibility of $\mathrm{P}$ and Ca of flounder fish. Vertebral P content was significantly affected by dietary Ca, IP, and phytase. Vertebral Ca content was influenced by dietary IP and phytase, not dietary Ca. Interaction between IP and phytase was found on vertebral $\mathrm{P}$ and Ca content and interaction between $\mathrm{Ca}$ and IP was observed on vertebral Ca and Ca:P ratio. Interaction between the three dietary $\mathrm{Ca}$, IP, and phytase was not detected in overall parameters.

\section{ACKNOWLEDGMENT}

The author would like to thank the Ministry of Education, Culture, Sport, Science, and Technology (Monbukagakusho), Japan for the financial support.

\section{REFERENCES}

Association of Official Analytical Chemists (AOAC). (1995). Official Methods of Analysis of Associa- tion of Official Analytical Chemists International. $16^{\text {th }}$ Ed. Association of Official Analytical Chemists, Arlington, VA. USA, 1141 pp.

Apines, M.J., Satoh, S., Kiron, V., Watanabe, T., \& Aoki, T. (2003). Availability of supplemental amino acidchelated trace elements in diets containing tricalcium phosphate and phytate to rainbow trout, Oncorhynchus mykiss. Aquaculture, 225, 431-444.

Applegate, T.J., Angel, R., \& Classen, H.L. (2003). Effect of dietary calcium, 25 hydroxycholecalciferol, or bird strain on small intestinal phytase activity in broiler chickens. Poultry Science, 82, 1140-1148.

Asgrad, T., \& Shearer, K. (1997). Dietary phosphorus requirement of juvenile Atlantic salmon, Salmo salar L. Aquaculture Nutrition, 3, 17-23.

Bureau, D.P., Kaushik, S.J., \& Cho, C.Y. (2002). Bioenergetics. In Halver, J.E., \& Hardy, R.W. (Eds.). Fish Nutrition. Academic Press, San Diego, California, USA, p. 1-59.

Coote, T.A., Hone, P.W., Kenyon, R., \& Maguire, J.B. (1996). The effect of different combinations of dietary calcium and phosphorus on the growth of juvenile Haliothis laevtgata. Aquaculture, 145, 267279.

Davis, D.A., \& Arnold, C.R. (1994). Estimation of apparent phosphorus availability from inorganic phosphorus sources for Penaeus Vannamei. Aquaculture, 127, 245-254.

Davis, D.A., \& Lawrence, A.L. (1997). Minerals. In D’Abramo, L.R., Conklin, D.E., \& Akiyama, D.M. (Eds.). Crustacean Nutrition, Vol. 6. Advances in World Aquaculture, p. 150-163.

Deshimaru, O., Kuroki, K., Sakamoto, S., \& Yone, Y. (1978). Absorption of labeled-45Ca by prawn from seawater. Nippon Suisan Gakkaishi, 44, 975-977.

Engelen, J.A., van der Heeft, F.C., Randsdorp, P.H.G., \& Smit, E.L.C. (1994). Simple and rapid determination of phytase activity. Journal of AOAC International, 77(3), 760-764.

Flik, G., van der Velden, J.A., Dechering, K.J., Verbost, P.M., Schoenmakers, T.J.M., Kolar, Z.I., \& Bonga, S.E.W. (1993). $\mathrm{Ca}^{2+}$ and $\mathrm{Mg}^{2+}$ transport in gills and gut in tilapia, Oreochromis mossambicus: A. Review. The Journal of Experimental Zoology, 265, 356-365.

Flik, G., Verbost, P.M., \& Wendelaar Bonga, E. (1995). Calcium transport processes in fishes. In Wood, C.M., \& Shuttleworth, T.J. (Eds.). Cellular and molecular approaches to fish ionic regulation. Fish Physiology, Vol. 14. Academic Press. San Diego, p. 317-342.

Folch. J., Lees, M., \& Sloanne-Stanley, G.H. (1957). A simple method for isolation and purification of total lipids from animal tissues. Journal of Biological Chemistry, 226, 497-509. 
Furukawa, A., \& Tsukahara, H. (1966). On the acid digestion method for the determination of chromic oxides as an index substance in the study of digestion of fish feed. Nippon Suisan Gakkaishi, $32,502-506$.

Haugh, W., \& Lantzsch, H.J. (1959). Sensitive method for the rapid determination of phytate in cereals and cereal products. Journal of Scientific Food and Agriculture, 34, 1423-1426.

Hilton, J.W. (1989). The interaction of vitamins, minerals and diet composition in the diet of fish. Aquaculture, 79, 223-244.

Hossain, M.A., \& Furuichi, M. (1999a). Necessity of dietary calcium supplement in black sea bream. Fisheries Science, 65, 893-897.

Hossain, M.A., \& Furuichi, M. (1999b). Dietary Ca requirement of giant croaker, Nibea japonica. Journal. Faculty of Agriculture, Kyushu Univ, 44, 99-104.

Hossain, M.A., \& Furuichi, M. (2000). Necessity of calcium supplement to the diet of Japanese flounder. Fisheries science, 66, 660-664.

Ichii, T., \& Mugiya, Y. (1983). Effects of a dietary deficiency in calcium on growth and calcium uptake from the aquatic environment in the goldfish, Carassius auratus. Comparative Biochemical and Physiology, 74A, 259-262.

Kemme, P.A., Schlemmer, U., Mroz, Z., \& Jongbloed, A.W. (2006). Monitoring the stepwise phytate degradation in the upper gastrointestinal tract of pigs. Journal of Science and Food Agriculture, 86, 612622.

Laining, A., Ishikawa, M., Kyaw, K., Gao, J., Binh, N.T., Koshio, S., Yamaguchi, S., Yokoyama, S., \& Koyama, J. (2011). Dietary calcium/phosphorus ratio influences the efficacy of microbial phytase on growth, mineral digestibility and vertebral mineralization in juvenile tiger puffer, Takifugu rubripes. Aquaculture Nutrition, 17, 267-277.

Laining, A., Ishikawa, M., Koshio, S., Lideman, \& Yokoyama, S. (2012). Dietary inorganic phosphorus or microbial phytase supplementation improves growth, nutrient utilization and phosphorus mineralization of juvenile red sea bream, Pagrus major, fed soybean-based diets. Aquaculture Nutrition, 18, 502-511.

Laining, A., Lideman, \& Ishikawa, M. (2013). Interaction between dietary mineral and phytase on biological performances of Japanese flounder, Paralichthys olivaceus. Part I. Growth, feed intake and whole body mineral content. Indonesian Aquaculture Journal, 8(1), 13-22.

Lall, S.P. (2002). The minerals. In Halver, J.E., \& Hardy, R.W. (Eds.). Fish Nutrition, $3^{\text {rd }}$ Ed. Academic Press, San Diego, CA, p. 259-308.
Lall, S.P., \& Lewis-McCrea, L. M. (2007). Role of nutrients in skeletal metabolism and pathology in fish - An overview. Aquaculture, 267, 3-19.

Liebert, F., \& Portz, L. (2007). Different sources of microbial phytase in plant based low phosphorus diets for nile tilapia Oreochromis niloticus may provide different effects on phytate degradation. Aquaculture, 267, 292-299.

Lowry, O.H., \& Lopez, J.A. (1946). The determination of inorganic phosphate in the presence of labile phosphate esters. Journal of Biological Chemistry, $162,421-428$.

McDowell, L.R. (1992). Mineral in animal and human nutrition. Academic Press. San Diego. USA.

Mugiya, Y., \& Watanabe, N. (1977). Studies on fish scale formation and resoption. II. Effect of estradiol on calcium homeostatis and skeletal tissue resorption in goldfish, Carrasius auratus and killifish, Fundulus heteroclitus. Comparative Biochemistry and Physiology, 57A, 197-202.

Rodehutscord, M. (1996). Response of rainbow trout (Oncorhynchus mykiss) growing from 50 to $200 \mathrm{~g}$ to supplement of dibasic sodium phosphate in a semipurified diet. Journal of Nutrition, 126, 324331.

Sardar, P., Randhawa, H.S., Abid, M., \& Prabhakar, S.K. (2007). Effect of dietary microbial phytase supplementation on growth performance, nutrient utilization, body compositions and haemato-biochemical profiles of Cyprinus carpio (L) fingerlings fed soyprotein-based diet. Aquaculture Nutrition, 13, 444-456.

Shearer, K.D., \& Asgard, T. (1992). The effect of water-borne magnesium on the dietary magnesium requirement of the rainbow trout (Oncorhynchus mykiss). Fish Physiology and Biochemistry, 9, 387392.

Tamin, N.M., Angel, R., \& Christman, M. (2004). Influence of dietary calcium and phytase on phytate phosphorus hydrolysis in broiler chickens. Poultry science, 83, 1358-1367.

Templeton, W.L., \& Brown, V.M. (1963). Accumulation of calcium and strontium by brown trout from waters in the United Kingdom. Nature, 198, 198200.

Toutenburg, H. (2002). Statistical Analysis of designed experiments. Second Edition. Springer-Verlac Inc., New York. USA.

Uyan, O., Koshio, S., Ishikawa, M., Uyan, S., Ren, T., Yokoyama, S., Komilus, C.F., \& Michael, F.R. (2007). Effects of dietary phosphorus and phospholipid level on growth, and phosphorus deficiency signs in juvenile Japanese flounder, Paralichthys olivaceus. Aquaculture, 267, 44-54. 
van der Velden, J.A., Flik, G., Spanings, F.A.T., Verburg, T.G., Kolar, Z.I., Wendelaar, \& Bonga, S.E. (1992). Physiological effects of low-magnesium feeding in the common carp, Cyprinus carpio. Journal of Experimental Zoology, 264, 237-244.

Vielma, J., \& Lall, S.P. (1998). Phosphorus utilization by Atlantic salmon, Salmo salar, reared in freshwater is not influenced by higher dietary calcium intake. Aquaculture, 16, 117-128.
Vielma, J, Ruohonen, K., \& Peisker, M. (2002). Dephytinization of two soy protein increases phosphorus and protein utilization by rainbow trout, Oncorhynchus mykiss. Aquaculture, 204, 145-156.

Watanabe, T., Murakami, A., Takeuchi L., Nose, T., \& Ogino, C. (1980). Requirement of chum salmon held in freshwater for dietary phosphorus. Bulletin of Japan Society of Science and Fisheries, 46, 361367. 